\title{
Despair and Homelessness in the face of Apocalypse: on Lars Von Trier's Melancholia and Andrey Zvyagintsev's Leviathan
}

Anik Sarkar is an Assistant Professor at the Department of English, Salesian College, India. His recent works include a chapter titled "I am a Tree Leaning: Neocolonialism, Eco-consciousness and the Decolonized Self in Margaret Atwood's Surfacing", in a book, upcoming from Lexington Books, Rowman \& Littlefield; a chapter titled "Between Horror and Hunger: Reflections on the Medical Poems of Miroslav Holub", upcoming in a book from Vernon Press, Delaware and a chapter on "Murakami and Videogames" for a book Ready Reader One, forthcoming from Louisiana State University Press. His work of fiction The Man who Sold Diseases, was published by Juggernaut Books, New Delhi, in 2018.

\section{Abstract}

Lars von Trier's Melancholia is about Justine and her apparent "schizo-" melancholy, one that shares its name with the planet about to crash on earth. While, Andrey Zvyagintsev's drama Leviathan, something inbetween grandiose and morbid hopelessness is Hobbesian; in the sense that power is monarchically vested but unlike the treatise, rights are not safeguarded and no freedom is guaranteed. It is a retake on the "Book of Job", but prayers are undertaken with cynicism as the lead character, Kolya's house is wrecked (literally and symbolically) we find a Church erected in its place while the camera pans to a picturesque landscape wary of the pervasive political corruption and endless human suffering in its immediate vicinity. As individuals are sloshed in vodka and boats lie wrecked on the shores of the city, skeletal remains of a whale mark the enormity of "Leviathan" from which there is no escape.

Even though both these films are surprisingly different in every other aspect, they centre on annihilation; one on the proper sense of the term: complete destruction, the later on the massacre of justice, rights and freedom. Also, "despair" and "isolation" follow one another in close coordinates that reveal the hopelessness of situation and a pervasive condition of "homelessness" - in Melancholia the symbols are strikingly evident while in Leviathan they are literal and obvious. This paper would 
aim to critically navigate through these films, analysing and comparing them while assessing their connections to "despair" and "homelessness" evident in the running year of the pandemic.

Keywords: Despair, homelessness, cinema, pandemic, hope.

\section{Introduction}

When I spend time contemplating on the pandemic, I cannot help thinking about the bubonic plague that surfaced in the seventeenth century, spreading across London like an immense black fog, unleashing death and suffering. I ruminate about the means people undertook to cope up in that unfortunate time, devoid of modern medicine, healthcare, regulated lockdowns and the internet. I then reflect on our present time-how swiftly the news spreads over Whatsapp or Facebook; how efficiently the number of cases can be traced and a detailed analytical report, contributed by several experts can be generated and instantly shared to the world, by interacting with a screen. Unanimously, we are all living in "viral" times, where "spreading" is not a bother, be it spreading of information across networks, or the uncontrollable spread of the virus; we have accelerated all possible scopes of "spreading" as the dawn of connectivity undergoes unprecedented improvisations.

Yes, we are more informed about the virus, about its approximate fatality rate and as the data that spikes everyday point us toward a future clouded in obscurity, we take certain precautions as advised by a body of medical professionals who constantly relay information on proper diet, exercises and mental health. We feel safe, even if it lasts for a short while. Because in the deep catacombs beneath our reasoning, there lurks a fear of the irrational, a despair that often embodies itself as a fear of death in the family or of a close person, outside it; in some cases we also imagine our own suffering in isolated wards, ventilation rooms and an eventual death, gradual and horrifying - the symbolic markers of which are abundant across popular media and they never fail to haunt.

As the alarming news of the coronavirus and its rapid haul over Asia, Europe and America, flashed across networks, we knew that it is 


\section{2 / Anik Sarkar}

Salesian Journal of Humanities and Social Sciences, Vol. XI, No.1 (May 2020)

ISSN: 0976-1861 | DOI: 10.51818/SJHSS.11.2020.40-54 | Page: 40-54,

Section: Articles

not a matter of few months, and that, we needed to stock-up supplies essentials first. It was then, that something of relevance occurred to me. I thought of cinema, and how, over the years, it has always played an important hand in educating its "connoisseurs" on the do's and don'ts during a global crisis. Even the most general audience of cinema, the ones who claim to be occasional movie-goers, have certainly watched plenty of those that simulate a zombie apocalypse, a natural disaster, alien invasion or devastation caused by super-sized animals. During the outbreak, a particular episode from a South Korean drama went viral as people claimed that it had predicted the outbreak of the coronavirus years ago. Another film called Contagion was massively recommended by those who could sense nodes of connection.

I too turned to cinema as a source of leisure as well as a critical stimulation as it is a welcome relief after substantial hours of work. As I was concerned about those who were trapped in unforeseen circumstances, far away from their home, while many like me were locked up at home, with our default movements under restriction, I wondered more about the concept of "home" and "homelessness". Why should being at home suddenly feel nauseating? Why so many, who were situated far from their hometowns, desperate to be at home, while those at home have become fidgety, wanting to move outside? To explore further, I decided to watch some films that were dystopian thematically, because somewhere, it would aid my research and also because of the fact that, I wanted to analyse how the characters react to an unforeseen predicament that might end up manifesting into an existential threat. I was reminded of Melancholia, which allegorically explores the idea of "home" and "homelessness" while I accidently stumbled upon a film, Leviathan, which too through its questioning of political machinery espouses the significance of home, security and "being home". Also, I thought about the fact that, films like these would perhaps, enlighten me on how to keep a steady balance during the "suddenness" of things and unanticipated situations which then would aid in kindling a form of hope, where usually, on the screen (more often than not) humanity manages to emerge safe and sound no matter the 
intensity of the potent apocalypse. We come to believe that quite unlike the mammoth dinosaurs, we are a surprise package (we even bred them and survived their threat under Spielberg).

But with Von Trier's Melancholia, things were different. Under very rare circumstances and across decades of filmmaking, did the unsuspecting viewer end up on a climax, where the annihilation is inevitable. Melancholia seems to be one of those films out of his oeuvre that is least gloomy! Why then, did I choose to re-watch this?

\section{Confrontation through Catharsis: Melancholia and Leviathan}

On returning to Von Trier's Melancholia, which Žižek refers to as being "profoundly optimistic,"1 I discovered things that I had missed many years back. What I could see this time is, how calm Justine appears during the apocalypse, while the more "sane" Claire and her husband panic in the latter half of the movie, at a time when everything: every discovery, story, material, meaning, Being and being, dissipates to nothingness. Justine's depression and "illness", precisely, a "schizo"- melancholy is during her marriage, the first apocalypse that she walks out of, her job the second and finally the "real" one, the more physical being the less depressing. She knows her way out, away from high culture (wine and terrace), high art (Beethoven), towards building a stick-piled magic cave for her nephew. This departure, away from sophistication of their "terrace" towards the primal, is her announcing the insignificance of it all: society, marriage, work. The house that Jack built, is then, truly of no use. Her knowing the insignificance is her knowing the "nothing," as she offers the tagline for Jack, she finally knows the "nothing," that equates everything she needs to know and hence the melancholy. This is not a nihilistic nod; it is more like: what do you feel, what else is there to do, after the meaning of the world is found?

${ }^{1}$ K. Jagernauth, “Watch: Philosopher Slavoj Žižek Explains Why Lars Von Trierıs «Melancholia' Is "Profoundly Optimistic"”, 2012. Indie Wire: https://www.indiewire. com/2012/07/watch-philosopher-slavoj-zizek-explains-why-lars-von-triersmelancholia-is-profoundly-optimistic-251438/ 


\section{4 / Anik Sarkar}

Salesian Journal of Humanities and Social Sciences, Vol. XI, No.1 (May 2020)

ISSN: 0976-1861 | DOI: 10.51818/SJHSS.11.2020.40-54 | Page: 40-54,

Section: Articles

On the other hand, another film that moved me at a similar interval, was Andrey Zvyagintsev's drama of grandiose hopelessness, Leviathan (2014). Even though one might be inclined to claim, that it is "Hobbesian", in the sense that power is monarchically vested; but unlike the treatise, rights are not safeguarded and no freedom is guaranteed. It is a retake on the "Book of Job", but prayers are undertaken with cynicism as Kolya's house is wrecked (literally and symbolically) we find a church erected in its place while the camera pans to an extensive, picturesque landscape wary of the pervasive political corruption and endless human suffering in its immediate vicinity. As individuals are sloshed in vodka and boats lie wrecked in the shores of the city, the skeletal remains of a whale mark the enormity of Leviathan from which there is no escape. Ruined buildings, demolished homes, corrupt officials and bleak livelihood looming high.

Like most films of Von Trier, the opening of Melancholia too, is characteristic of an artistic flurry-bricolage of footages from the film and some symbolic frames including one that situates the lead character "Justine" as Ophelia, floating away in the water draped in her wedding gown. Likewise, this film is a storehouse of imagery and symbolism where disciples of film and literature would be delighted to intervene and discover the "easter eggs" 2 for themselves. The last clip of the opening shows the slow obliteration of earth by the approaching planet, Melancholia, a scene much that drastically transforms into a more painful viewership when repeated in the end.

There are two sections in the film, each bearing the names of the two women characters on the lead. The first one is "Justine" and it opens with a playful girl on her marriage day stuck in a Limousine that fails to take a turn in a bend at a hill, owing to its elongated body. It results in a delay while the guests had been waiting for the couple to arrive since hours. Justine's childlike playfulness is further demonstrated when she leaves the guests waiting, in order to talk to her horse "Abraham." As a belief

\footnotetext{
${ }^{2}$ See "Easter eggs" in Wikipedia: https://en.wikipedia.org/wiki/Easter_egg. In media, an "Easter egg" is popularly associated with videogames and films that carries hidden messages, images or jokes within its storyline.
} 
held typically and duly represented across film and literature, that for a woman, "marriage" is the most important event apart from childbirth, and where characters spend the first half of their lives romanticizing and planning about it, Justine's approach to marriage is a foil to the aforementioned. She seems unbothered about its importance, as time and again she seems less and less interested. She shows a lack of interest while participating in most of the events and performs acts with an unbothered/non-caring attitude. She ends up sleeping with a stranger on the day of her marriage in a dramatic fashion, and foul mouths her boss. In doing so, Justine breaks away from all that is significant for a person: marriage, income and social relations. This demolishing carnage of Justine continues throughout the film, where she is at first, unable to understand the reason of her being such.

Justine is a part of a family that has severely disintegrated. Her mother is portrayed to be rude, uncaring, while her father as playful, careless and inconsiderate. During her day of wedding, in the speech supposed to be addressed to Justine and her new beginning, he shifts the focus of his talk on his ex-wife whom he calls "domineering", which erupts in a bitter argument with his ex-wife and Justine's mother who says she doesn't believe in marriage, going on to say to the newlyweds: "[e] njoy it, while it lasts." Justine's husband is shown to be unremarkable, compared to Justine and her striking abilities, be it as a suffering artist, a courageous woman or as we figure out in the end, an enlightened spirit. From his inability to deliver a basic speech, his lack of practical thinking when he places a guess of two million beads during the lottery while the bottle appears to hold something significantly less; to his incapability of handling Justine, where he fails to sustain the image of a proper husband for Justin who deserts him on the day of their marriage. As her brother in law, John, constantly reminds them of the rich venue and the amount spent, while Tim, a new employee at Justine's workplace has been forced to pursue Justine, in order to get a tagline for an advertisement on the day of her marriage, we are aware of the materialistic undercurrents that lie beneath and govern social systems and social relations. 


\section{6 / Anik Sarkar}

Salesian Journal of Humanities and Social Sciences, Vol. XI, No.1 (May 2020)

ISSN: 0976-1861 | DOI: 10.51818/SJHSS.11.2020.40-54 | Page: 40-54,

Section: Articles

The elaborate party, with its sophistication and rich maneuver fails to sustain etiquettes and decency - beneath it, is plainly visible a crumbling social order, where all the grandness and décor that was fashioned in a celebratory gesture for the coming together of two souls, seeks to compensate the inherent loss of familial bond. In her despair, Justine realizes that there is something bigger approaching her, which empowers her to walk out of all "essential" ties. With her mother asking her to "[g]et the hell out of here", when she says she is scared and needs help, to Tim endlessly following her to get a tagline, there is much less to be done. The melancholy of Justin sustains, as a result of this deep familial problem, but it is not the sole cause for her despair. Melancholia, here, is an extended term for despair, leaving just enough room for Sartre's conception to slip in-of the non-caring attitude to what one cannot control. ${ }^{3}$ It is on one hand, the agitating feeling of deprivation and on the other, the waiting for an end to come after an almost saintlike realization of truth. It is the painful feeling of leaving everything behind, juxtaposed with the higher understanding of purpose and fulfillment - one that completes the quest of a suffering artist, accepting his or her mortality, while also contemplating on the immortal essence of the artistic produce.

When confronted with the brutal, shattering absurdity that annihilates all life founding principles, individuals start to lose their sanity. It is the withering away of all that was structured, principled, indoctrinated - when the asignifying ${ }^{4}$ chaos, in its unfathomable depth, and de-structured incarnation starts to gaze at them. Such confrontations can be utterly devastating, as the states of meaning and coherence begin to rupture and thoughts do not lead to any viable solutions. It is at this precise moment that fear and despair are in its prime, overcoming

\footnotetext{
${ }^{3}$ N. Warburton, "A Student's Guide to Jean-PaulSartre's Existentialism and Humanism", Philosophy Now, 1996. https://philosophynow.org/issues/15/A_students_guide_ to_JeanPaul_Sartres_Existentialism_and_Humanism\#: :text=Despair $\% 2$ C $\% 20$ like $\% 20$ abandonment $\% 20$ and $\%$ 20anguish,Hell \%20is\%20other\%20people $\%$ E2\%80\%9D.

${ }^{4}$ I have used "A signifying" to denote a sign that does not point to an agreed upon reality. See, "asignifying" in the context of Guattari. G. Genosko, "Information and Asignifcation", Footprint 8, 1(2014): 13. https:/ / doi.org/10.7480/footprint.8.1
} 
the rationale of the self and collapsing the comfort of all familiarities including self-identity. The idea of "home" as a space of comfort, a stronghold that fortifies the occupants from undesirable elements, starts to wither.

In the first half of the film, during the event of their marriage, a game of lottery is held where participants have to bid on the number of beads. Later in the film, announcing the number of beads in the bottle, Justine proclaims that she knows things. She confirms that, "[w]e are alone," as individuals stranded in a planet. Her dispersion from all earthly ties and essentials, including the separation from each family member, along with job and marriage stands for her firm belief in the universal quality of isolation. She claims, "[1]ife is only on earth and not for long." The scientism and rationality of John is defeated, as he gives into suicide, unable to withstand the failure of his intellect that outstood all his existential ties. As the approaching planet enlarges through the makeshift measuring apparatus, Claire's despair takes on an overwhelming weight and she loses her composure. On the other hand, Justine is calm and stoic, negating all the high, luxurious, sophisticated approach to accept "the end" - moving away from the idea of gathering in the terrace, with a glass of wine and a song to making a stick-pile magic cave with her nephew, a form of last refuge, a tribute to the earliest known shelter to mankind - the cave. Denouncing all sophistication and embracing primacy is Justine's way of approaching the apocalypse. By going to the bare root of where it all began, she resurrects a home, stabilizing the collective unity of a family (something that she lacked throughout her life up to this instance). The child, who is still far from constructs and Justine who denounced all constructs has a different demeanor to the approaching annihilation than Claire, who still in the grasp of despair, cries as she is unable to let go off her worldly attachments.

Leviathan too communicates the plight of deteriorating relationships, first between a step-mother and her step-son while the film then proceeds gradually towards a wreckage of all sorts of social bonding, across relations. The absence of etiquettes feature early on, as the young 


\section{8 / Anik Sarkar}

Salesian Journal of Humanities and Social Sciences, Vol. XI, No.1 (May 2020)

ISSN: 0976-1861 | DOI: 10.51818/SJHSS.11.2020.40-54 | Page: 40-54,

Section: Articles

kid shares his disgust with his step mother, anger and the brute force of toxic masculinity ensemble in the youth as his father hits him "playfully" in front of his visiting friend, and later kicks his son, instigating him to rival in a battle of fists. Kolya's anger and impatience is pervasive, which leads him into trouble at a police station, in a place where the governing institutions are bent against him. Their house stands on a disputed land, which the mayor of the town seeks to purchase leading to a row of legal battles.

Despair gathers momentum like strong sea-currents, in the life of the lead character, with his property under dispute, his son triggered with the presence of his step-mother and his wife cheating on him with his best friend who also is their lawyer. It appears as a crisis of faith, of justice and of basic rights. For the wife, the sin of adultery, guilt of shaming and loss of Kolya's trust results in a feeling of intense despair. She perhaps feels that her act of adultery had further pushed the case away from their grasp, as the family lawyer wouldn't be in a position to defend his friend after having an illicit affair, getting caught with his wife in broad daylight. Further shaming by his step-son and questioning by their family friend deepens her sense of guilt, as she wanders away to the edge of a cliff, that overlooks the sea and drowns herself, as her despair extends and gives way to self-decimation.

For Kolya, this bleak confrontation was an extension to his already enflamed grief. His loss of faith in God and the State becomes apparent as he talks to the priest about his despair and meaninglessness, which leads him to extreme alcoholism as an escape to an overarching despair. As he is framed for the "murder" of his wife with planted evidences, it becomes clear that no justice is to be served. Kolya's home is bulldozed short after his family and the sense of 'peace' and 'security' that compliments the feeling of 'homely' are dissociated. Ironically, a church is erected on the remains of his home, where the mayor comes to pray with his family, in a city where justice and goodness ceased to function. Kolya's despair about a loss of home, both literal and metaphorical: one the physical dwelling with bricks, wood and concrete, the other, his family, manifests into a haunting reality. An enormous whale skeleton 
near the river beds, abandoned buildings and wrecked houses remind the audience that even the gigantic structures are not spared from annihilation. In the film, the choice of the title "Leviathan" could have an ironical significance as the treatise of Leviathan ${ }^{5}$ which upholds justice and rights, is rendered useless and trivial through the rampant abuse of power, and as the film closes, the words of the priest who proclaims that "Freedom" is finding "God's Truth," falls on deaf, cynical ears of the corrupted mayor who acts pious in front of his son.

\section{The Place of Despair}

Kierkegaard wrote intensively on "despair" in his seminal text, The Sickness unto Death and as per him: "despair is a kind of sickness of spirit, stemming from a misunderstanding of who we actually are as human beings." ${ }^{6}$ Kierkegaard paradoxically refers to despair as a sickness unto death, yet as in the proper sense of sickness that can cause death, despair is not the literal sickness that can lead on to the death of the body, "the torment of despair is precisely this, not to be able to die." ${ }^{7} \mathrm{He}$ then remarks that, "to be sick unto death is not to be able to die," ${ }^{\prime \prime}$ even though, one seeks death, the hopelessness does not allow a culmination of the "last hope" - death. At a time when death is the only great danger and a hope, despair is the condition that refutes such a hope for death, manifesting a discontentment of not being able to die. Despair develops as an iterating, self-consuming phenomenon that fails to release a man seeking release from his "self." As Grunthaler observes, Kierkegaard's conception of despair is universal, affecting all lives just as some form of sickness affects all humans that exist, "a disquietude, a perturbation, a discord, an anxious dread of an unknown something, or of a something

\footnotetext{
${ }^{5}$ See Hobbes on "justice". T. Hobbes (1651), Leviathan: Or, The Matter, Form And Power of a Commonwealth, Ecclesiastical and Civil, 8. http://www.mesacc.edu/ barsp59601/ text/105/notes/read/historical/hobbes.pdf

${ }^{6}$ A.J. Grunthaler, "Kieregaard's Concept of Despair," Sophia Project, 2018: 2. http:// www.sophia-project.org/uploads/1/3/9/5/13955288/grunthaler_despair.pdf

${ }^{7}$ Ibid, 2.

${ }^{8}$ Ibid.
} 


\section{0 / Anik Sarkar}

Salesian Journal of Humanities and Social Sciences, Vol. XI, No.1 (May 2020)

ISSN: 0976-1861 | DOI: 10.51818/SJHSS.11.2020.40-54 | Page: 40-54,

Section: Articles

he does not even dare to make acquaintance with, dread of a possibility of life, or dread of himself" 9 and "one who without affectation says that he is in despair is after all a little bit nearer, a dialectical step nearer to being cured than all those who are not regarded and who do not regard themselves as being in despair."10 Humans aware of despair are closer to get it resolved, while those who deny it are in a far deeper trench.

As I discuss Paradise Lost Book I with my undergraduate students, I cannot but help think of Milton's Satan and his state of despair. Was he conscious or unconscious of his despair? Probably the former, as he looks around, surmounted with dejection, submerged in an immolating lake of gloom, his loss of the eternal garden, his fall from bliss to eternal despair, "[w] hat reinforcement we may gain from hope, [i]f not what resolution from despair." 11 Perhaps then, the overtly used phrase, "I am going through Hell!" when someone asks us, how "sincere" have we been during the lockdown, somehow reminds us of Satan drowned in despair, as he contemplates the loss of Paradise, his feet scorching in the agonizing sulfur. But then, Satan looks forward to the consolation from despair in his current state (in the original Hell), a feat astoundingly forlorn unless one is in a state of constant confabulation and consoles his/her self under the spell of self-deception.

For, Sartre, who echoing Nietzsche's belief in the loss of morality at the dawn of modernity, saw "abandonment" as a call to action. ${ }^{12}$ The position of the modern, anxious man, riddled with apprehension and in the seat of despair, is one that Sartre tries to uncover. He is concerned with "choice" and "freedom" in an oblivious world, where suddenly,

\footnotetext{
${ }^{9}$ Ibid, 3 .

${ }^{10}$ Ibid.

${ }^{11}$ J. Milton \& P. Pullman, Paradise Lost, (New York: Oxford University Press, 2005), 2223.

${ }^{12}$ N. Warburton, "AStudent's Guide to Jean-PaulSartre's Existentialism and Humanism", Philosophy Now, 1996. https://philosophynow.org/issues/15/A_students_guide_to_ JeanPaul_Sartres_Existentialism_and_Humanism\#: :text=Despair $\% 2$ C $\% 201 i k e \% 20$ abandonment $\% 20$ and \%20anguish,Hell\%20is\%20other\%20people\%E2\%80\%9D.
} 
the promising ordeal of "Enlightenment" collapses. ${ }^{13}$ Responsibilities of the "self," making authentic choices and steering away from what he calls "bad faith"14 are the fundamentals of negotiating with modern absurdities - things that are in effect universally as the responsibility is "extended": "Sartre would argue that the fact that existentialists actually increase the scope of responsibility beyond its usual domain, making each of us responsible for a whole image of humankind"15 Despair for Sartre, is not a pitfall and a loss of complete hope. Despair is indifference and "acting without hope" knowing that certain conditions are beyond our control or predictability. It is an awareness of the uncertain; of the fact that the choices of other people are beyond our control. This does not call for hopelessness or nonchalance, rather it calls for action and an exercise of existential choice, embarking on "freedom" and "authenticity." 16

The despair that we inhabit, at this point in time is different from how Sartre sees it. Despair has never been so reluctant a feeling as it continues to burrow deep within our collective recesses. We act with hope, with a head bent toward resilience; we battle despair and strive to keep it at the margins. We distract ourselves from the daily visitations of despair, through activities, or, participate in acquiring new skills, meanwhile substituting "despair" with a more unapologetic and a criminally underrepresentative term, "boredom". Perhaps, we are too afraid admitting to ourselves and to others that we are wandering deep inside the caves of a prowling despair. We repress it, treat it like a momentary trauma, but unlike most traumas that are events from the past (for instance, war or

${ }^{13}$ Ibid. Also see Sartre's concept of "choice" and "freedom". J. Jones, "Jean-Paul Sartre's Concepts of Freedom \& "Existential Choice", Explained in an Animated Video Narrated by Stephen Fry, Philosophy, 2018.

http:/ / www.openculture.com/2018/02/jean-paul-sartres-concepts-of-freedomexistential-choice-explained-in-an-animated-video-narrated-by-stephen-fry.html.

${ }^{14}$ See Sartre's concept of "bad faith". T. Flynn, "Jean-Paul Sartre", The Stanford Encyclopedia of Philosophy, Fall 2013. https://plato.stanford.edu/archives/fall2013/ entries/sartre/

${ }^{15}$ N. Warburton, "A Student's Guide".

${ }^{16}$ See Sartre's concept of "authenticity". B. Yacobi, "The Limits of Authenticity", Philosophy Now, 2012. https:// philosophynow.org/issues/92/The_Limits_of_Authenticity 


\section{2 / Anik Sarkar}

Salesian Journal of Humanities and Social Sciences, Vol. XI, No.1 (May 2020)

ISSN: 0976-1861 | DOI: 10.51818/SJHSS.11.2020.40-54 | Page: 40-54,

Section: Articles

childhood), we are living and experiencing a collective trauma. Even if for a certain section of the population, the pandemic meant a recession and nothing more, the despair and anxiety never really disappeared, appearing less frequently now as compared to the earliest months - the more habitual we get to conformity and restricted spaces. But we are aware of how stealthy it lurks in the shadows and how brutally it may strike, even if the calling seems faint.

\section{Home and Homelessness}

News and social media flood us with stories of displacement. Thousands of workers return home from distant places of work. Some who went for studies or treatment were stuck up in cities, some who have spent fortunes in transportation, and some for whom such means are a fading dream, they cycled hundreds of miles. Many took the extreme step of waking, across states going on and on without having an access to basic necessities. "Home" is a symbol of safety and comfort, of nourishment and rest. It is where the heart longs to return, if we are away or outside. It is the most secure space we can relate to, as the earth too is a popular connotation of "home." When there is the question of returning home, there is a longing, a strong desire to unite with the loved ones; a commitment to build a home is often one amongst an individual's strongest aspirations, flashed as a symbol of "success." This year, the urge to return home has been felt like never before, as millions of stranded employees, students, daily-wage labourers, businessmen, tourists - people belonging to various vocations and spread all across the world, and those staying away from home, have experienced univocally. It is hard, not to wonder about the gamut of privilege I have in the comfort of simply being at home, while for thousands the comfort of a home can only arrive after an Odyssean journey. Who would have thought that in a matter of days, for so many among us, "home" would become inaccessible?

More so, in the time of an approaching apocalypse be it the fear of an invading army of aliens, (Arrival, Independence Day, Extinction) or during an environmental/natural crisis (Snowpiercer, The Day After Tomorrow, 
2012)or for that matter, a viral outbreak, (I am Legend, Contagion, Here Alone), the concept of "homelessness" radiates from these films, as an indisputable and patent spectacle. We immediately associate extinction as a separation from our collective home. In Melancholia, the audience is exposed to the loss of a collective home, while Leviathan jolts them to the underside of losing the personal home. Perhaps, the despair that rises in the characters of both these films, is the fear of losing home, to be rendered homeless - to lose one's home becomes equal to losing one's very existence. Hence, we see Justine in Melancholia, under a spell of desperation, gathering sticks from a forest and raising a makeshift home as a final resistance to annihilation and the biting despair.

All that Kolya tries to do and ends up losing is, in fact, in his attempt to safeguard his home from the evil snatch of the governing body. Similarly, the despair that haunts many such stranded individuals: where "homelessness" becomes a synonym for despair; those who are stuck in cities different from their own, or in nations that are not their 'home'-lands; a common, universal desperation to return home; a euphony of voices, resounding the melodies of homecoming; a cerebral sickness for the strange, unpredictable virus, and longing to unite with all that is familiar and homely.

For those, who have finally managed to return from abroad or distant cities, they too aren't liberated from feeling of "despair" and "homelessness," as they are held up in quarantine centres. I cannot imagine the suffering one undergoes, being in the hometown and yet a far cry -for whom the pleasures of home are deferred. Those who are self-quarantined, being at home isn't homely enough. They have to wait for around fourteen days, to feel completely at home; safe from the virus and "virality." Those of us, who still are safe from the contagion, are sharing a weaker, throbbing version of that same despair and anxiety thinking about a possibility of having a contact, which will then lead to a feeling of 'homelessness'; perhaps the feeling of separation from home, and the idea of being at a hospital or a quarantine centre has amplified our despair to manifolds. Under recent circumstances, the concepts of "home," "health," "family," "familiar", "known" and "safe" 


\section{4 / Anik Sarkar}

Salesian Journal of Humanities and Social Sciences, Vol. XI, No.1 (May 2020)

ISSN: 0976-1861 | DOI: 10.51818/SJHSS.11.2020.40-54 | Page: 40-54,

Section: Articles

appear synonymous to us while everything that is "outside", have the tendency to be characterized as "insecure", "invisible", "unfamiliar", "strange", "viral", "infectious."

As the recent news enlivens us with the promise of a vaccine, the despair shrinks at a corner - a little more. As trains carrying the weary populace arrive at $\mathrm{NJP},{ }_{1}^{17}$ or planes that "rescue" those who had been stuck in foreign cities, land in Bagdogra, ${ }^{18}$ I can only imagine the joy in the hearts of people, for whom returning home during a global crisis is same as being dragged into an unforeseen battle which has been courageously fought, and won. As for me, I think of Santiago in The Alchemist - where the treasures he is looking for, that takes him to distant lands far from home, ends up being in the same place where he slept and conceived his original dream.

17 "NJP" is the abbreviated form for "New Jalpaiguri", a railway station near Siliguri, in the state of West Bengal, India.

18 "Bagdogra" is a small town that has an international airport nearest to the town of Siliguri, in the state of West Bengal, India. It is where the author resides. 